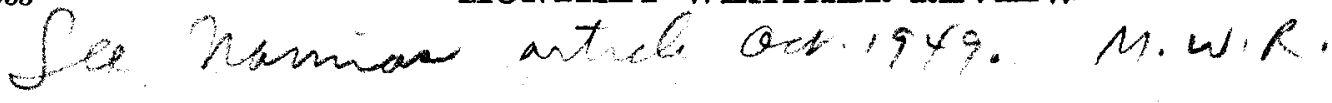

\title{
FORECASTING WINTER PRECIPITATION 36 TO 48 HOURS IN ADVANCE AT DES MOINES, IOWA
}

\author{
An Experiment Using the Prognostic Chart as a Data Source
}

\author{
SIDNEY TEWELES, JR., AND ALBERT L. FORST \\ Short Range Forecast Development Section, U. S. Weather Bureau, Washington, D. C. \\ [Manuscript received November 5, 1953]
}

\begin{abstract}
To determine the accuracy with which a precipitation forecast can be made from the features of the prognostic charts currently disseminated, an objective forecast system using only those features has been developed for the Des Moines, Iowa, area. As a means of finding predictors, sets of composite sea level and 700-mb. charts were made up for very dry situations and for situations in which heavy precipitation occurred. In the final system, the various predictors are combined in scatter diagrams to give a forecast, comparable in accuracy with that of the district forecast, of the occurrence of precipitation at Des Moines during a 12-hour period beginning 12 hours after the valid time of the 30-hour sea level prognostic chart.
\end{abstract}

\section{CONTENTS}

Introduction

Selection of the forecast problem .

Familiarization with the area. . . . . . . . .

Composite charts

Development of objective system

The search for parameters.

The 700-mb. parameters

The sea level parameters

Forecast categories

Using the system.

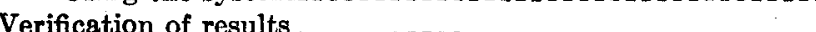

Quantitative forecasting

A comparison with the district forecasts.............

Application of the foreeasts to other stations...........

Conclusion

References

\section{INTRODUCTION}

In the last ten years, increasing emphasis has been placed on the use of the prognostic chart as an auxiliary aid to weather forecasting. To improve the quality of the charts, typing and analogue systems, kinematic equations, objective aids, and graphical techniques have been devised. More recently Charney [1] and others have designed mathematical procedures amenable to performance by electronic computers. Such recent efforts to improve prognostic charts have raised the important question of the manner in which predictors derived from prognostic charts may be used in forecasting weather.

The work described here is one of the several studies (for example $[2,3,4])$ in which the prognostic chart is used as a source of predictors upon which the occurrence of some weather element is dependent. In this study, a forecast system was developed using perfect prognostic charts of the surface and $700-\mathrm{mb}$. level, that is, actual weather maps but consisting of only those items to be found on currently transmitted prognostic charts. The completed forecast system was tested on an independent series of perfect prognostic charts. This test indicates the degree to which the system is independent of the particular period covered by the charts used in developing the system. A further test was then made using the prognostic charts from the independent series. This test has the purpose of measuring both the skill of the system under actual working conditions and the amount by which the skill drops off due to the lack of identity between features of the actual prognostic and perfect prognostic charts.

The principal aim of this study was to get a measure of the skill that may be attained in forecasting precipitation through the use of prognostic charts. Since we are looking forward to a time when prognostic charts will be made by the electronic computer using numerical methods, the skill of the prognosticator is eliminated as a variable by the use of predictors taken from perfect prognostic charts. There remains the question of how much prognostic charts will ultimately be improved by the use of numerical methods.

\section{SELECTION OF THE FORECAST PROBLEM}

Precipitation was chosen as the element to be forecast. The initial problem attempted here was to devise a system of forecasting the precipitation for the daytime hours of one day (0630-1830 CsT) from the prognostic charts valid the previous evening. This forecast, as issued. by the district and local forecasters, is made in the even-

$281432-54-2$ 
ing two days earlier from the $1830 \mathrm{csT}$ surface chart and 0900 csT upper air charts. Available to the forecaster are the prognostic 30 -hour surface and 36 -hour $700-\mathrm{mb}$. charts valid the following evening at 1830 and $2100 \mathrm{csT}$, respectively. It is from these prognostic charts that the data for the method to be described are obtained, although in developing the method actual observed charts (perfect prognostics) for those times were used.

Several parts of the United States were considered in selecting a locality for which to forecast. A study by Bristor on the selection of forecast research problems [5] indicated that forecasting aids would be very useful in the region between the Mississippi River and the Rockies. Des Moines was selected within this region because of its central location within its area of service responsibility.

Some thought was given to working out the system so that it would be applicable to all seasons of the year, but because of the many differences between precipitationproducing situations in the warm and cold months, the system constructed applies only to the months of December, January, and February.

\section{FAMILIARIZATION WITH THE AREA}

Familiarization with the preciptiation-producing synoptic situations of central Iowa was aided by lists, made for each of the 4 seasons, of 10 dates on which large amounts of precipitation occurred within the selected 12 hours and 10 dates on which there was no precipitation in the Des Moines area. For this purpose 3 months were assigned to each season, e. g., "winter" consists of December, January, and February. In order that the noprecipitation dates should represent exceptionally dry conditions, it was further specified that there be no precipitation in the entire State on that date and none at Des Moines for at least 2 days before and after. Most of the dry days were actually in periods of severe drought. Cases were selected, not from the entire period of record, but only from the period since November 13, 1945, for which map data are available on punched cards.

Although examination of the individual maps was of value in learning to recognize weather potentialities, the possibility remained that important indications beyond the immediate vicinity of the forecast area would go unnoticed. For this reason, the 8 lists of 10 dates described above were submitted to the Weather Bureau's Machine Tabulation Unit where punched cards containing sea level pressure data at $1830 \mathrm{csT}$ and $700-\mathrm{mb}$. height data at 2100 csT for the western half of the Northern Hemisphere were processed to get average pressure and height values from which composite sea level and 700-mb. charts, for dry and precipitation situations were plotted and analyzed.

\section{COMPOSITE CHARTS}

The composite charts for the winter season are shown in figures 1-4. Several important differences between the dry and wet situations are apparent. Dry conditions accompany a strongly developed subtropical high pressure belt between $30^{\circ}$ and $40^{\circ} \mathrm{N}$, with strong zonal flow from $40^{\circ}$ to $55^{\circ} \mathrm{N}$., since in this situation, traveling cyclones with their attendant precipitation pass north of the Des Moines area. Heavy precipitation is preceded by a trough aloft west of Des Moines; surface Lows move in from the southwest but pass to the south of the city.

The composite charts can be treated in various ways to bring out their essential differences. Although some differences, such as the path of contours running from Des Moines to the west or the strength of the westerly currents through northern Washington and Montana, are evident at a glance, a more objective means is necessary to bring out the more subtle differences between the two sets of charts. For this purpose the following auxiliary charts were prepared:

a. Pressure difference (fig. 5) and height difference (fig. 6) between dry and precipitation composites. Isopleths of the pressure (or contour) difference form a pattern which may be studied to find axes along which the pressure (or contour) gradient difference between charts is a maximum.

b. Relative topography (mean isotherms) and mean flow between sea level and 700-mb. composites. With these charts, the advection patterns of the sea level to $700-\mathrm{mb}$. layer may be compared.

c. Sea level and 700-mb. composites of the charts 24 hours earlier than the initial set of charts.

d. Composite pressure and height change in the 24 hours preceding the time of the initial set of charts.

\section{DEVELOPMENT OF THE OBJECTIVE SYSTEM}

\section{THE SEARCH FOR PARAMETERS}

Initially, the patterns of the sea level and 700-mb. composites and of the auxiliary charts (figs. 1-6) were examined to find parameters related to one or more of the primary precipitation variables: moisture supply, thermodynamic instability, and lifting mechanism. Since only situations of heavy precipitation make up the precipitation composites, it was necessary to examine the less homogeneous situations associated with small amounts of precipitation to define additional types of precipitation producers.

The parameters selected are, in general, related to more than one of the primary precipitation variables. This is particularly true in the case of southerly wind components in the lower levels, for not only does the principal moisture source lie to the south, but also southerly winds tend to occur with approaching troughs with whose eastern portions are associated convective instability and several types of lifting mechanism. The lifting mechanism may be upglide of the warm moist air over a slower moving cold airmass, sudden lifting of the warm moist air by a cold front, the pre-frontal squall line, or quite often some less definable process such as might be associated with a great field of divergence in the high levels of the troposphere with upward motion between it and a compensating field of convergence in the lower levels. As shown by Klein [2] 


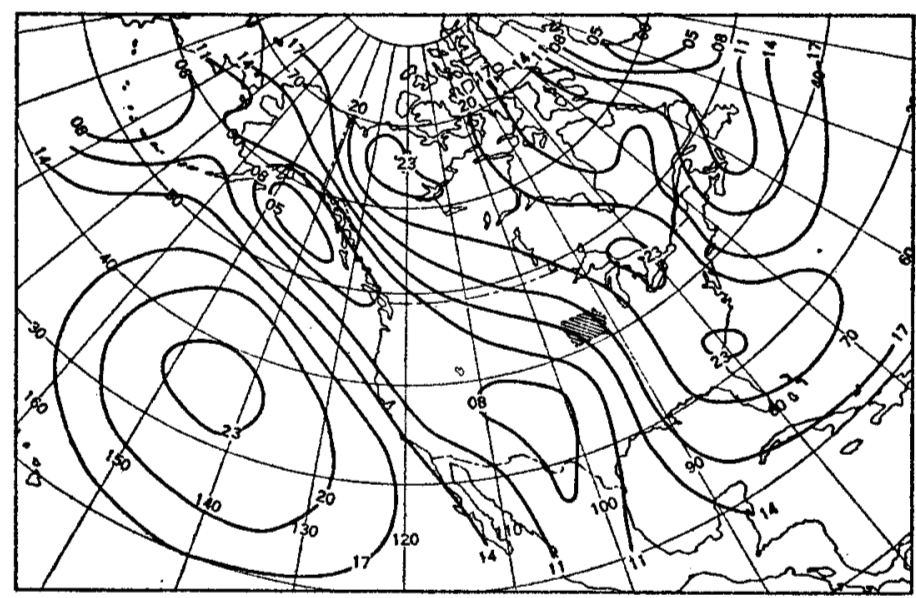

Fiodra 1.-Composite sea level pressure chart for ten winter cases of heavy 12-hour precipitation at Des Moines, Iowa. Isobars are labeled in millibars, hundreds omitted. State of Iowa is Indicated by shading.

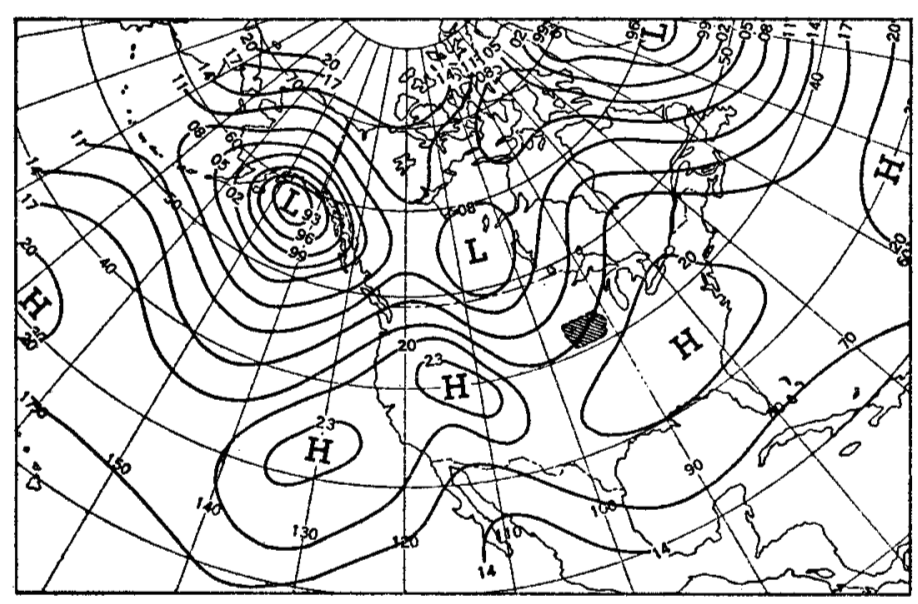

Froun: 2.-Composite sea level pressure chart for ten winter cases of dry conditions at Des Moines. Isobars are labeled in millibars, hundreds omitted. State of lowa is indicated by shading.

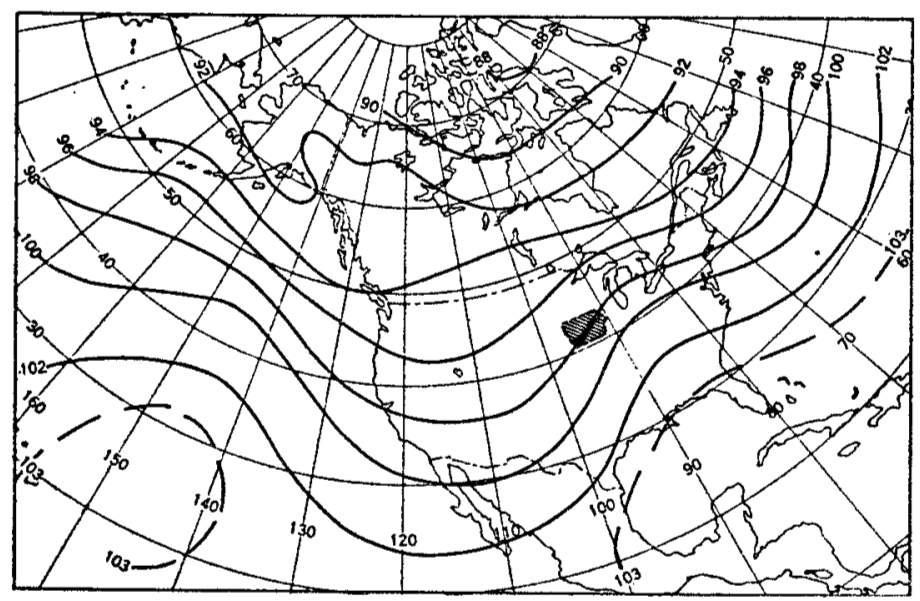

FIGURz 3.-Composite 700-mb. chart for ten winter cases of heavy 12-hour precipitation at Des Moines (same cases used for flg. 1). Contours are in hundreds of feet. State of Iowa is indicated by shading.

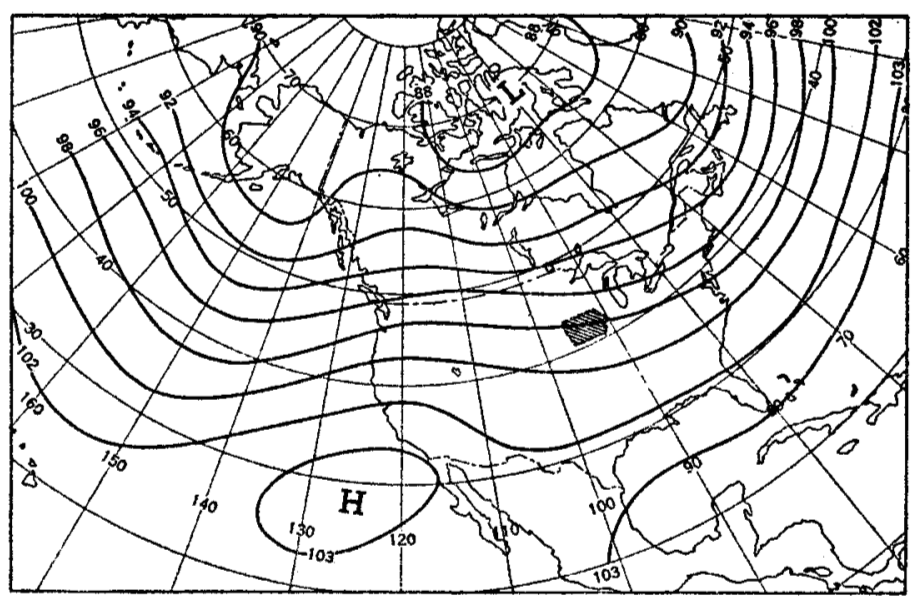

Fravan 4.-Composite 700-mb. chart for ten winter cases of dry conditions at Des Moine (same cases used for fig. 2). Contours are in hundreds of feet. State of Iows is indicated by shading.

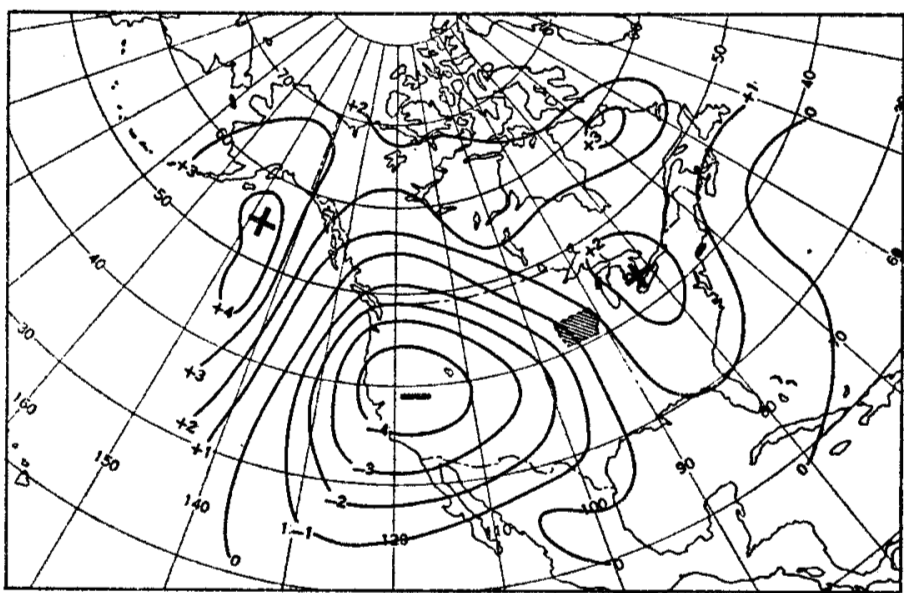

FIOURE 5-Pressure difference chart, in millibars, computed by subtracting ses level pressure on composite charts for dry conditions (fig. 2) from sea level pressure on composite charts for heavy 12-hour precipitation (fig. 1). State of Iowa is indicated by shading.

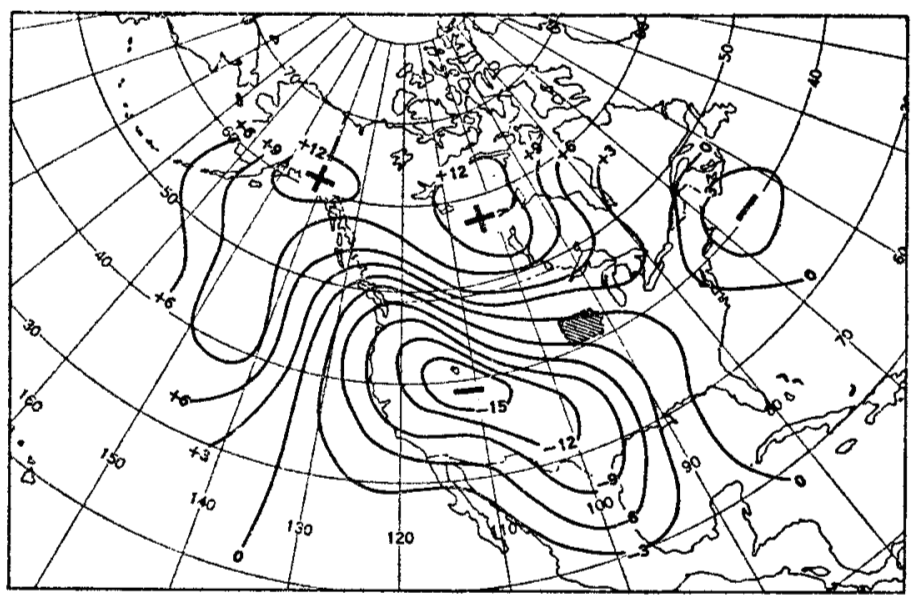

Frour x 6.-Helght difference chart, in hundreds of feet, computed by subtracting 700-mb. height on composite charts for dry conditions (fig. 4) from $700-\mathrm{mb}$. height on composite charts for heavy 12-hour precipitation (fg. 3). State of Iowa is indicated by shading. 
and Riehl [6] conditions favorable for precipitation are most likely to be found in the portion of an upper-level wave pattern from the trough line eastward to the next ridge.

The difficulty of the forecasting problem in this area is increased by the fact that, especially in winter when the mean westerly component over the Iowa area is large, the State is often in the rain shadow of the mountain ranges to the west. Very often the flow in the lower levels does originate in the Gulf of Mexico area but the very storm whose approach brings the necessary lifting mechanism drives before it a large mass of dehydrated air, effectively deflecting to the east of Des Moines the tongue of moist air flowing from the south. Precipitation then tends to break out along and beyond a northeast-southwest line not very far to the east of Des Moines. This line separating the area having little or no precipitation from the area of heavier precipitation is usually so well marked that we refer to it as the "arid line."

Figures 7 and 8 illustrate the array of parameters which at one time or another were tested in this study. The majority of these were selected by careful examination of the various composite charts. Some form of stratification was greatly desired, so the first parameters selected were taken from the areas where the patterns in figures 5 and 6 are most dissimilar.

\section{THE 700-MB. PARAMETERS}

Comparison of the 700-mb. composites (figs. 3 and 4) with the aid of the difference chart (fig. 6) shows that heavy precipitation at Des Moines is associated with southerly wind components in the area from the Continental Divide to the Mississippi River, while dry conditions tend to occur when there is west-northwesterly flow in that area and a ridge at $120^{\circ} \mathrm{W}$. These observations suggest that a measure of the wind flow in this area should be useful as a predictor.

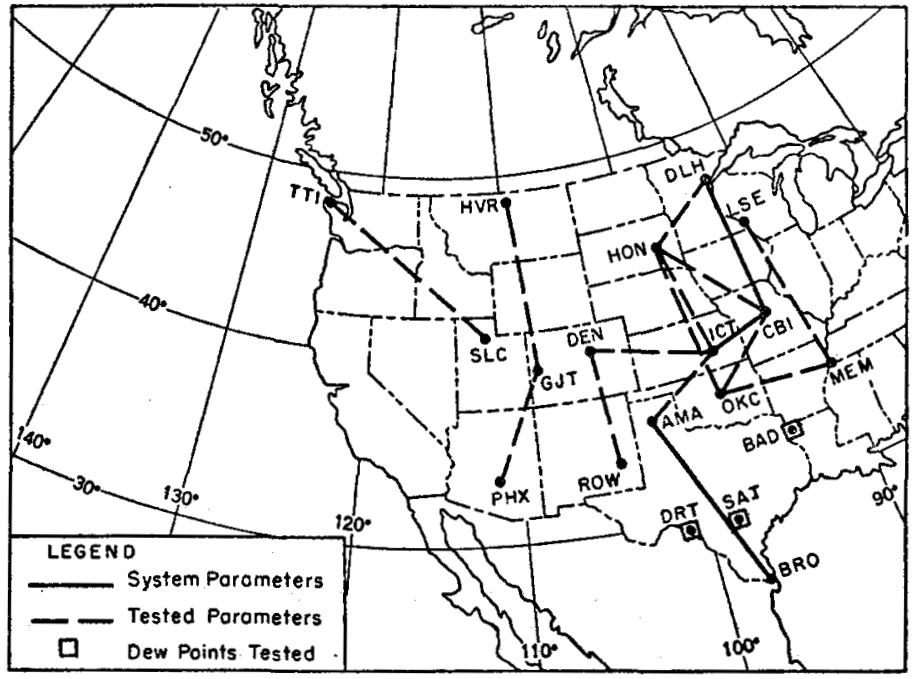

Fiaure 7.-Map of sea level parameters used in the system or tested during the investigation. Joined points indicate pressure difference parameters.
The best of the parameters selected from the area are the height differences, Columbia, Mo. minus North Platte, Nebr. $\Delta \mathrm{H}_{\mathrm{CBI}-\mathrm{LBF}}$, and North Platte minus St. Cloud, Minn. $\Delta \mathrm{H}_{\mathrm{LBF}-\text { sTC. }}$ When combined in a scatter diagram (fig. 10), this pair measures the mean geostrophic wind over the Columbia-North Platte-St. Cloud triangle centered slightly to the west of Des Moines. Parameters complementing rather than duplicating the resolutions of cases attained in figure 10 are difficult to find. Only two of the other upper air parameters tested showed any success in this regard, the height differences Dodge City, Kans., minus Columbia, $\Delta \mathrm{H}_{\mathbf{D D C}-\mathrm{CBr}}$, and Oakland, Calif., minus $\mathrm{N}\left(32.5^{\circ} \mathrm{N}, 1^{\circ} \mathrm{W} .\right)^{*}, \Delta \mathrm{H}_{\mathrm{OAK}-\mathrm{N}}$. The parameter $\Delta \mathrm{H}_{\mathrm{OAK}-\mathrm{N}}$ serves to measure the north-south wind component just off the west coast. Strong north winds in this area are associated with developing trough situations inland which in turn often produce precipitation over Iowa. Strong southerly components just off the west coast, on the other hand, are a clue to the presence of a ridge over the western two-thirds of the United States, and therefore a dry condition over lowa. At times, however, such a ridge has buried within it a trough at lower latitudes. The height difference $\Delta \mathrm{H}_{\mathrm{DDC}-\mathrm{CBI}}$, is designed to detect such a precipitation producer.

The parameters $\Delta \mathrm{H}_{\mathrm{CBI}-\mathrm{LBF}}$ and $\Delta \mathrm{H}_{\mathrm{LBF}-\mathrm{sTC}}$ were combined in a single diagram (fig. 10) with precipitation as the variate plotted within the diagram. An analysis of: this diagram according to the method described in the next section results in a family of lines from which may be: read off the values of a dependent variable $X_{2}$. In the same way the height differences $\Delta \mathrm{H}_{\mathrm{OAK}-\mathrm{N}}$ and $\Delta \mathrm{H}_{\mathrm{DDC}-\mathrm{CBr}}$ were combined in a single scatter diagram (fig. 12) to give: values of the dependent parameter $\mathrm{X}_{4}$.

* Point $\mathrm{N}$, during the period of the observations used in this study, was the location of Ship $\mathrm{N}$. On December 6, 1953, Ship $\mathrm{N}$ was moved to $31^{\circ} \mathrm{N}$., $140^{\circ} \mathrm{W}$. Therefore, from maps after that date the $700-\mathrm{mb}$. height for use in determining $\Delta$ HoAr-N should be interpolated for the former location.

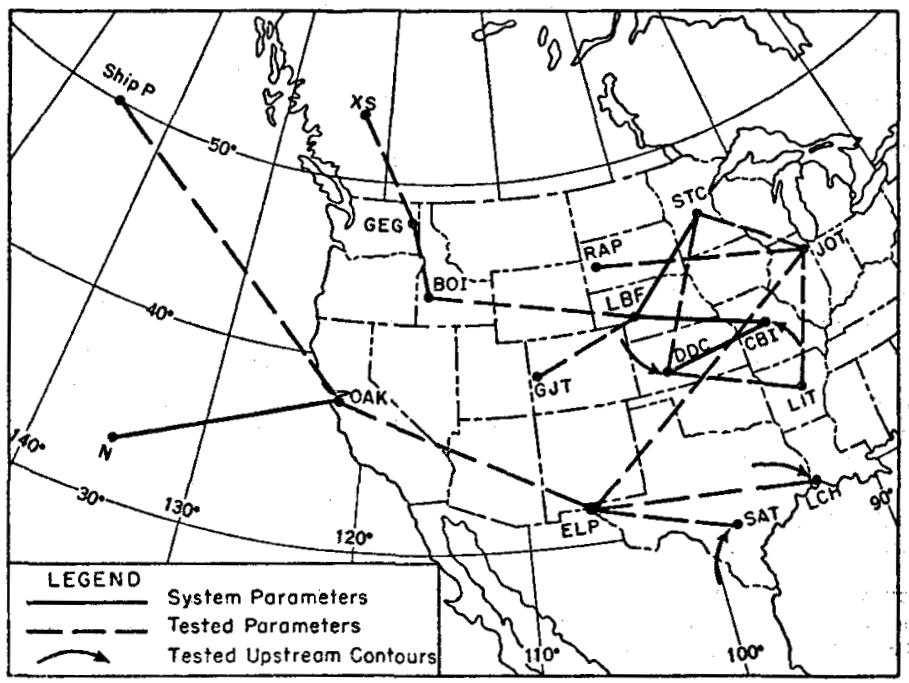

Fiaure 8.-Map of 700-mb. parameters used in the system or tested during the investigation. Joined points indicate height difference parameters. 
THE SEA LEVEL PARAMETERS

From an examination of the sea level composites (figs. 1 and 2) and the difference chart (fig. 5) a number of pressures and pressure differences were selected, again from areas of greatest flow difference. These parameters were tested against the observed precipitation to find those which not only are most closely related to precipitation occurrence but which also tend to add information to that already obtained from the 700-mb. parameters.

The pressure differences Wichita, Kans. minus Columbia, Mo. $\triangle \mathrm{P}_{\text {ICT-CBr, }}$ and Columbia minus Duluth, Minn. $\Delta \mathrm{P}_{\mathrm{CBI}-\mathrm{DLH}}$, which when combined in a scatter diagram (fig. 9) give an indication of the mean surface wind over the Wichita-Columbia-Duluth triangle, were found to be the most helpful of the sea level parameters. However, each of these two pressure differences has a special significance. $\Delta \mathrm{P}_{\mathrm{ICT}-\mathrm{CBI}}$ is a timing, or "cut-off", parameter testing whether a storm is approaching or is no longer a threat. $\Delta \mathrm{P}_{\mathrm{CBI} \text {-DLH, }}$ on the other hand, is an indirect measure of the slope of the isentropic surfaces between Columbia and Duluth. Analysis of this scatter diagram results in a family of curves of the variable $X_{1}$.

A second pair of sea level parameters, the pressure at
Amarillo, Tex. $P_{A M A}$, and the pressure difference between Brownsville, Tex. and Amarillo, $\Delta \mathrm{P}_{\mathrm{Bro}-\mathrm{Ama}}$, is used to give the values of the dependent variable $X_{3}$ (fig. 11). The parameter $P_{A M A}$, tends to measure the seriousness of the threat southwest of Des Moines, while $\Delta \mathrm{P}_{\mathrm{BRO}-\Delta M A}$ serves to diminish this value in the case of excessive westerly components.

Parameters $X_{1}$ and $X_{2}$ were combined (fig. $13 Y_{1}$ ) to give another dependent variable $Y_{1}$, essentially a function of the surface and the 700-mb. wind over the Des Moines area.

$\mathrm{X}_{3}$ and $\mathrm{X}_{1}$ were also combined (fig. $13 \mathrm{Y}_{2}$ ) to allow evaluation of another dependent variable $\mathrm{Y}_{2}$, which is a rough measure of a wave pattern aloft and the availability of moisture in the lower layers. A last combination was made of $Y_{1}$ and $Y_{2}$ as dependent parameters, again with precipitation as the plotted variate, to form the $\mathrm{Z}$ chart (fig. 14).

The use of one more sea level parameter, the pressure difference between Columbia and Huron, N. Dak. $\Delta \mathrm{P}_{\mathrm{CBI}-\mathrm{HON}}$, is required to resolve the cases falling into the $\mathrm{Q}$ area of the $\mathrm{Z}$ chart. This parameter is an additional measure of the surface wind over the Iowa area.

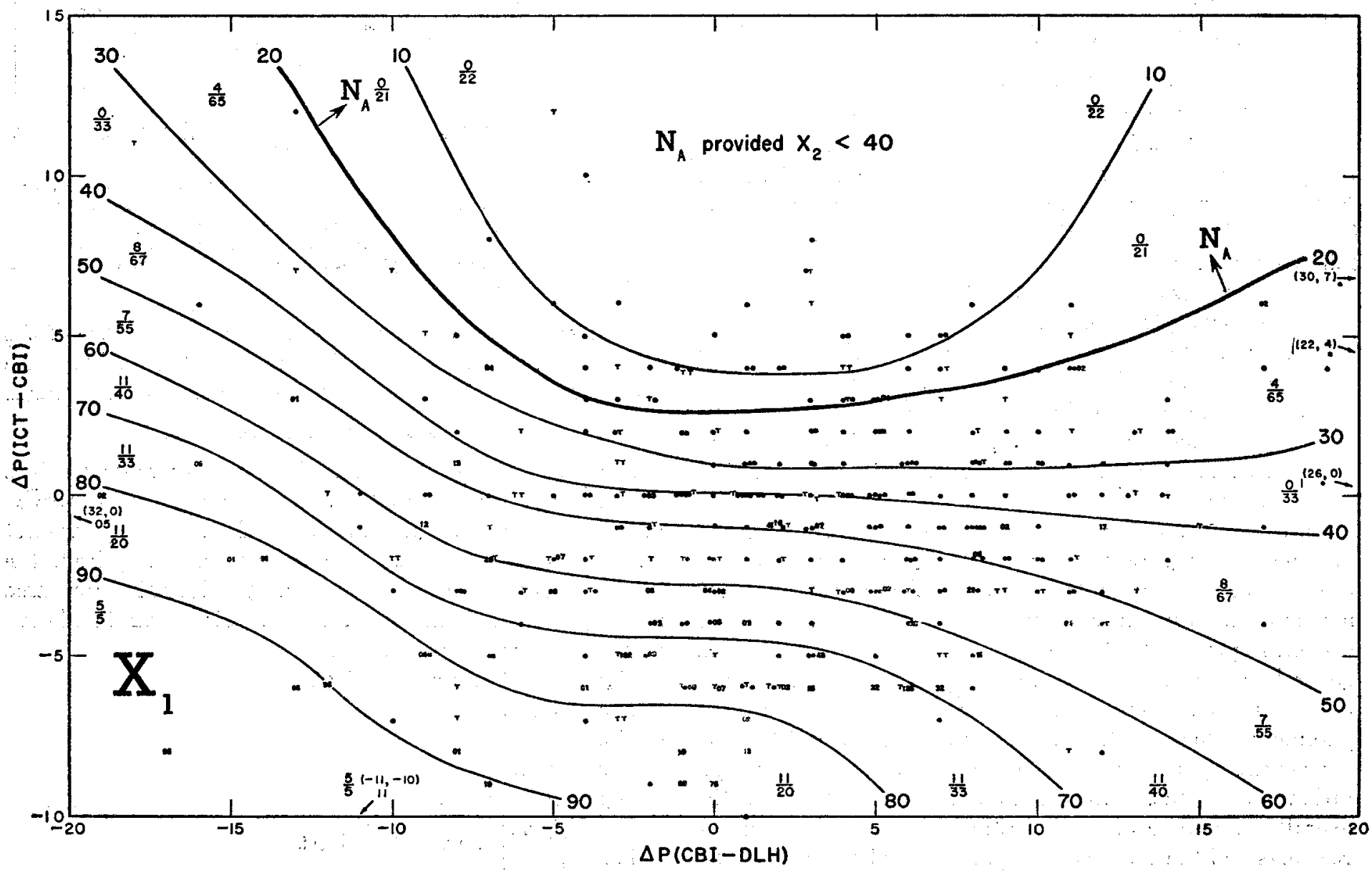

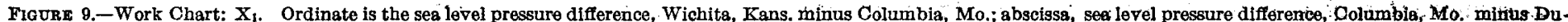

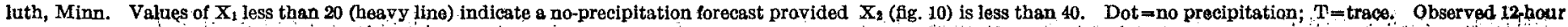
precipitation amounts are in hundredths of an inch. The fractions between parametric lines are ratios of precipitation cases to total cases within the two lines." 


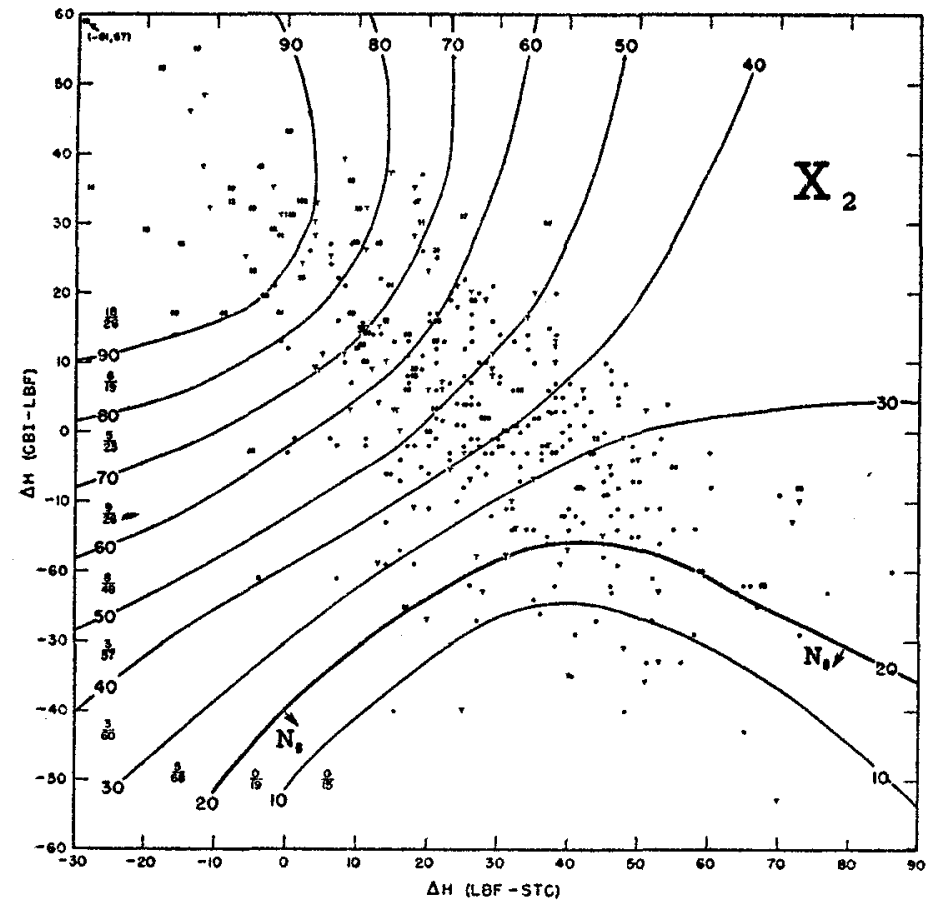

Fucuex 10.-Work Chart: $X_{1}$. Ordinate is the $700-\mathrm{mb}$. height difference Columbia, Mo. minus North Platte, Nebr.; abscissa, 700-mb. height difference, North Platte. Nebr. minus St. Cloud, Minn. Values of $X_{2}$ less than 20 (heavy line) indicate a noprecipitation forecast. Dot=no preclpitation; $T=$ trace. Observed 12-hour precipitation amounts are in hundredths of an inch. The fractions between parametric lines sre ratlos of precipitation cases to total cases within the two lines.

\section{ANALYSIS OF THE SCATTER DIAGRAM}

On each of the scatter diagrams a family of curves numbered by tens from 10 to 90 has been drawn subjectively but with attention to a large amount of detail. Not only were precipitation amounts for the proper 12hour period entered on the working charts but also the following information:

1. Amounts occurring in the 6 hours preceding and/or following the period.

2. Amounts occurring in the proper period at certain stations within 50 miles of Des Moines.

3. Additional cases in which amounts of more than 0.25 inch occurred in months of November and March adjacent to the winters of the dependent sample.

Both the percentage of precipitation reports and the presence of large amounts were considered in analyzing the charts. Although the values assigned to the parametric lines do not have a precise physical meaning, they are arranged so that the higher values correspond in general to a greater probability of precipitation and to a greater probable amount. The values assigned to the parametric lines on the four $X$ charts (figs. 9-12) have approximately the same meaning with respect to precipitation occurrence. On the two $\mathrm{Y}$ charts (fig. 13) the overall percentage of precipitation is higher than on the $\mathrm{X}$ charts and the values of the parametric lines correspond to somewhat higher percentages and amounts of precipitation. Attempts made to analyze the charts with families of lines defined with respect to just one type of

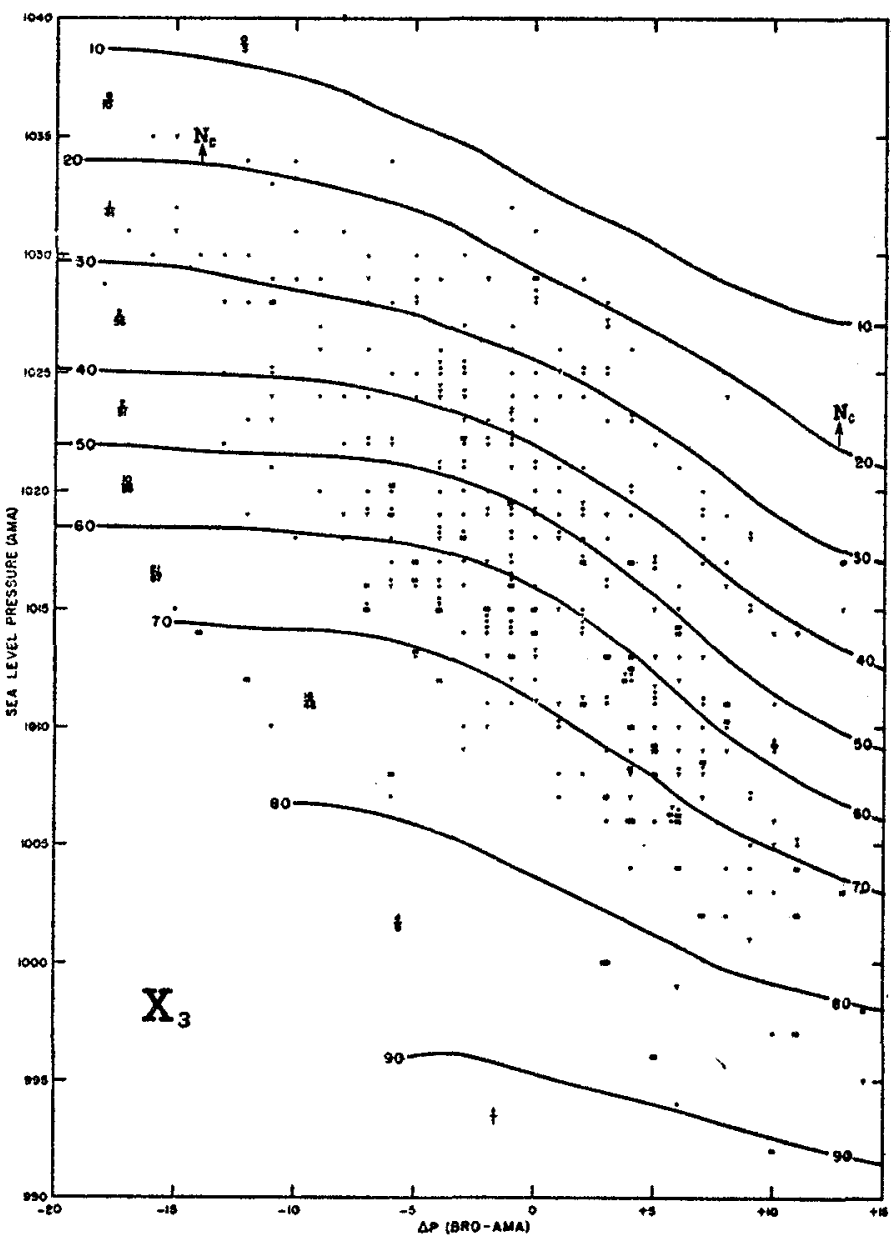

Fioure 11.-Work Chart: $X_{3}$. Ordinate is the sea level pressure at Amarillo, Tex.; abscissa, sea level pressure difference, Brownsville, Tex. minus Amarlllo. Values of $\mathrm{X}$, less than 20 (heavy line) indicate a no-precipitation forecast. Dot $=$ no precipitation; $\mathrm{T}=$ trace. Observed 12-hour precipitation amounts are in hundredths of an inch. The fractions between parametric lines are ratios of preclpitation cases to total cases within the two lines.

precipitation statistic showed little promise because of the low frequency of precipitation at Des Moines and the resulting sparse distribution of precipitation on the charts.

\section{FORECAST CATEGORIES}

From the analyzed scatter diagram, parametric values for each case were extracted and compared with observed precipitation to establish limits for the necessary forecast categories. To facilitate the bookkeeping required, the symbols $N_{1}$ are used to indicate no-precipitation forecasts and $R_{1}$, precipitation forecasts. Requirements for definitions of the categories follow.

$\mathrm{N}_{\mathrm{A}}: \mathrm{X}_{1}<20$ and also $\mathrm{X}_{2}<40$

$\mathrm{N}_{\mathrm{B}}: \mathrm{X}_{2}<20$

$\mathrm{N}_{\mathrm{C}}: \mathrm{X}_{3}<20$

$\mathrm{N}_{\mathrm{D}}: \mathrm{X}_{4}<20$

$N_{\mathrm{E}}: X_{1}<59$ for all $i$

$\left.\begin{array}{l}R_{1}: Y_{1} \geq 65 \\ R_{2}: Y_{2} \geq 65\end{array}\right\} R$ area of $Z$ chart

$N_{\mathrm{Z}}: \mathrm{N}$ area of $\mathrm{Z}$ chart

$N_{Q}: Q$ area of $Z$ chart and $\Delta P_{C B I-B O N}>0$

$R_{Q}: Q$ area of $Z$ chart and $\Delta P_{C B I-\text { HON }} \leq 0$ 


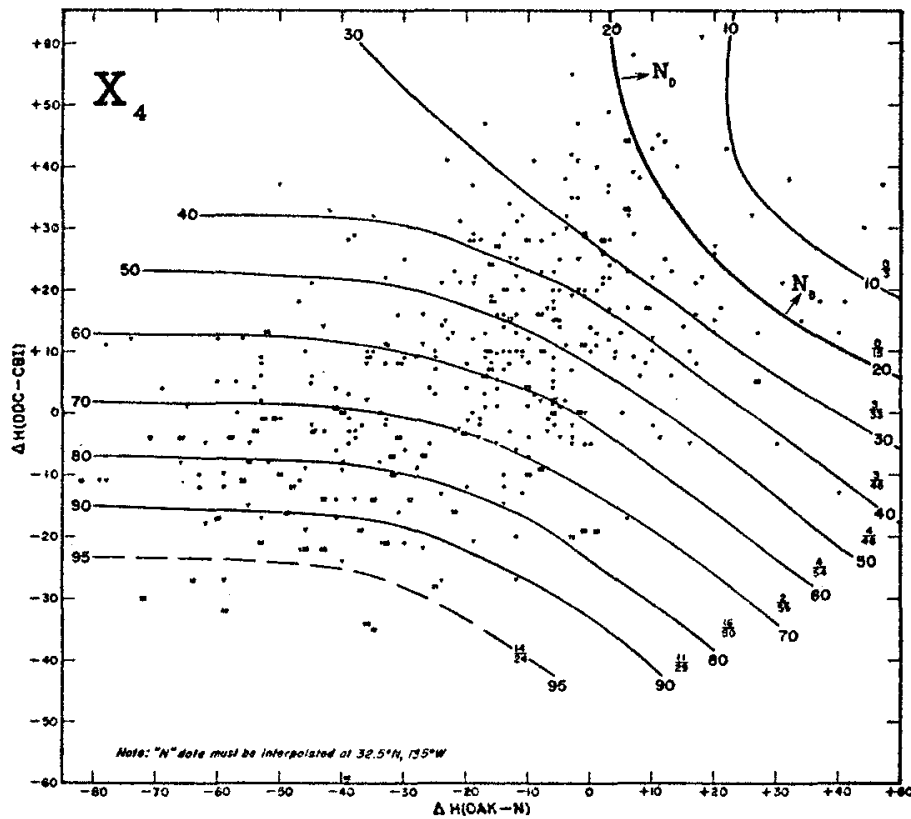

Figviz 12.-Work Chart: $X_{1}$. Ordinate is the 700-mb, beight difference Dodge City, Kans. minus Columbia, Mo.; abseissa, 700-mb. height difference, Oakland, Caltf. minus $\mathrm{N}, 32.5^{\circ} \mathrm{N} ., 135^{\circ} \mathrm{W}$. (former location). Values of $\mathrm{X}_{4}$ less than 20 (heuvy line) indicate a no-precipitation forecast. Dot $=$ no precipitation; $T=$ trace. Observed 12-hour precipitation amounts are in hundredths of an inch. The fractions between parametric lines are ratios of precipitation cases to total cases within the two lines.

The relative frequency with which precipitation occurred in these categories for both dependent and test data is given in table 1.

\section{USING THE SYSTEM}

The steps leading to a forecast are summarized in figure 15. Sea level pressures for Wichita, Columbia, Duluth,

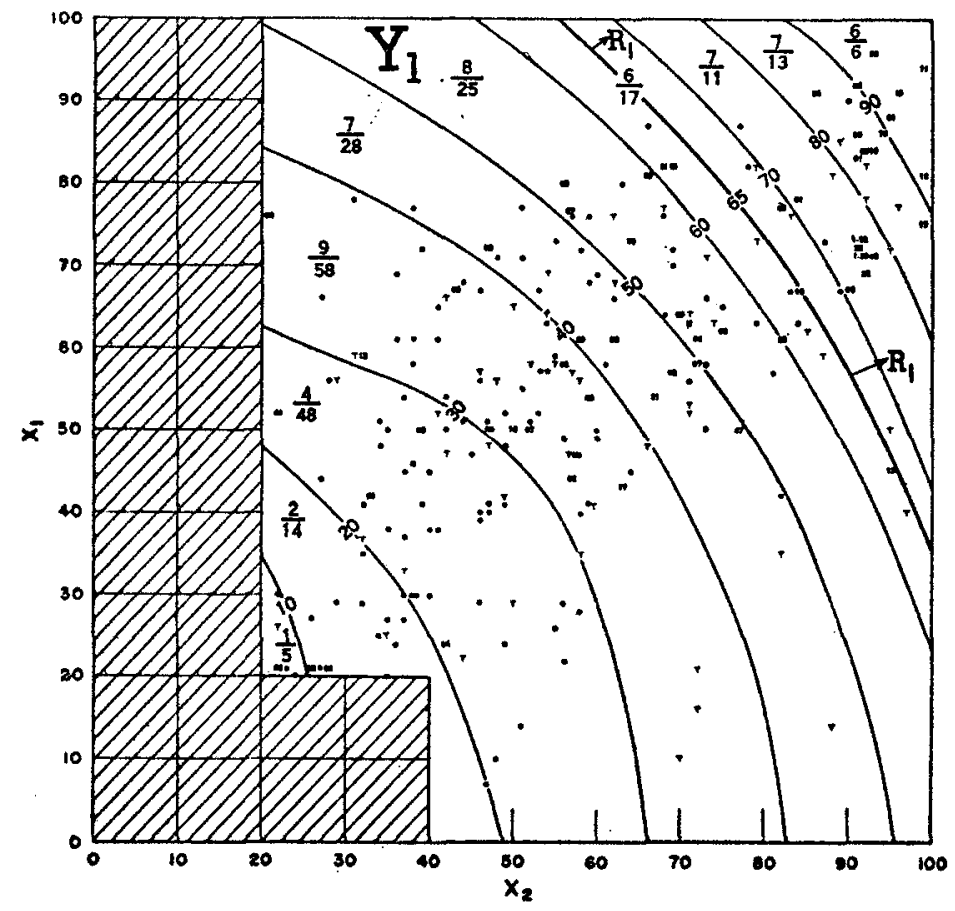

Brownsville, Amarillo, and Huron and 700-mb. heights for Columbia, North Platte, St. Cloud, Oakland, point N $\left(32.5^{\circ} \mathrm{N} ., 135^{\circ} \mathrm{W}.\right)$, and Dodge City must be interpolated from the prognostic charts. For more than one-third of the cases, a forecast of $N_{1}(i=A, B, C, D$ or $E)$ is given by the value of one or more of the $X$ parameters and the process need be carried no further. The $R_{1}$ and $R_{2}$ forecasts (about one-eighth of all cases) follow directly from the values of the $Y$ parameters. About one-half of all the cases must be carried into the $Z$ chart.

Figure 16 is a sample work sheet illustrating the manner in which the data can be arranged for daily use and monthly tabulation. Some of the steps are omitted when the forecast is reached at an early stage.

\section{VERIFICATION OF RESULTS}

Two of the more usual scores used in verifying forecasts are the percentage correct and the skill score. Although both of these scores have certain advantages each has serious deficiencies when used in testing systems such as this. The percentage correct has the disadvantage of being deceptively high in the regions where precipitation is infrequent. For example, if one forecasts no precipitation for every one of the 722 winter daytime periods included in this study, his score will be 85 percent correct. Since, in the Iowa area, a forecaster does well if precipitation occurs on just half of those days on which he forecasts it, it will be seen that even this good forecaster will end up with a score of 85 percent correct. The use of the percentage correct diminishes his incentive to try anything but a no-precipitation forecast. But the skill score

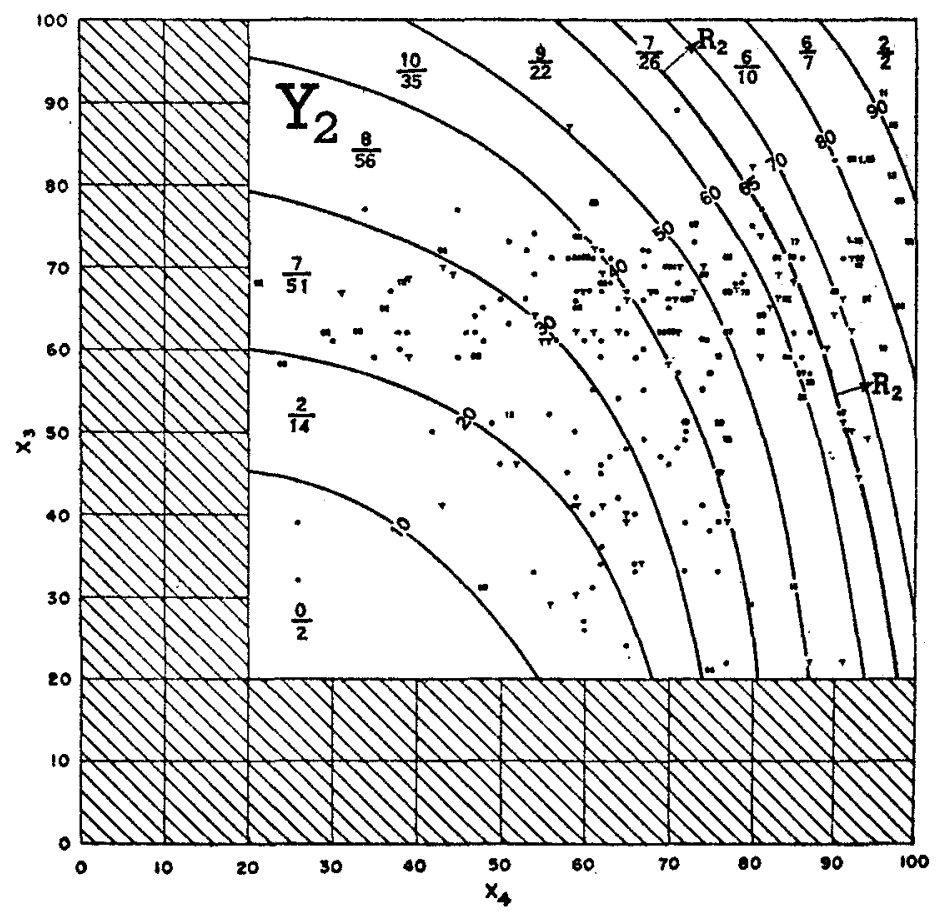

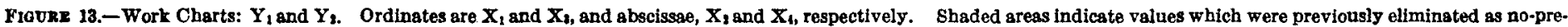

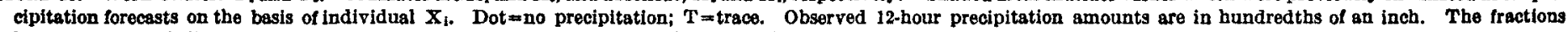
between parametic lines are ratios of precipitation cases to total cases within the two lines 


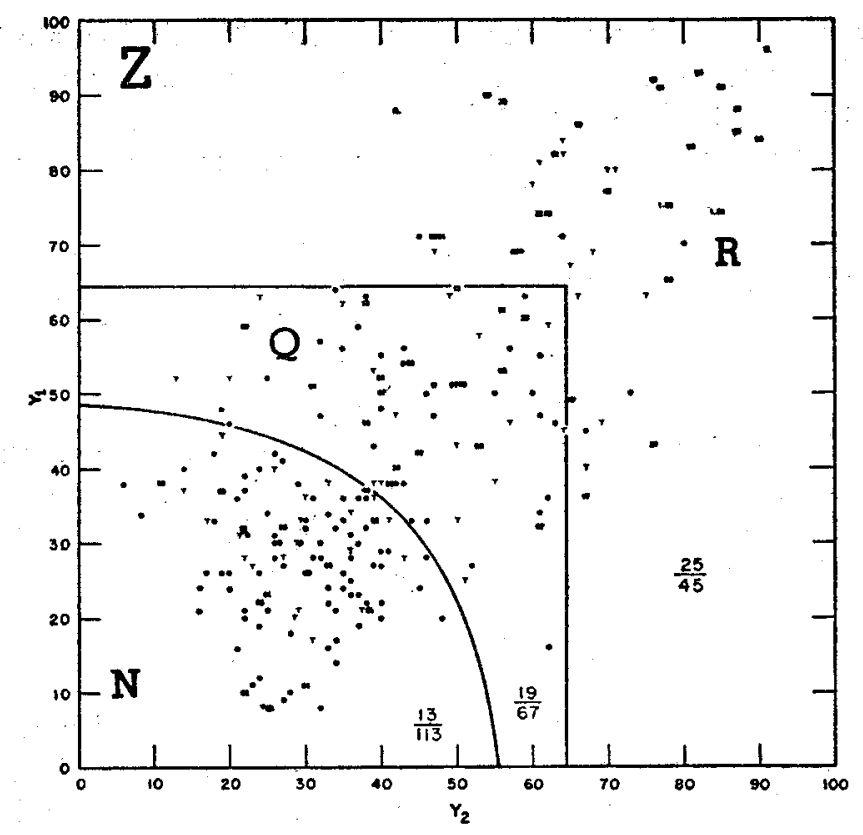

Fioure 14.-Work Chart: $Z$. Ordinate and abseissa aro $Y_{1}$ and $Y_{2}$ respectively. The N area indicates a no-precipitation forecast; the $\mathbf{R}$ area, a precipitation forecast. The $Q$ area indicates a precipitation forecast unless $\triangle P C B I-H O N$ is greater than zero. $D o t=$ no precipitation, $T=$ traco. Observed 12-hour precipitation amounts are in hundredths of an inch: Fractions are ratios of precipitation cases to total cases within each area.

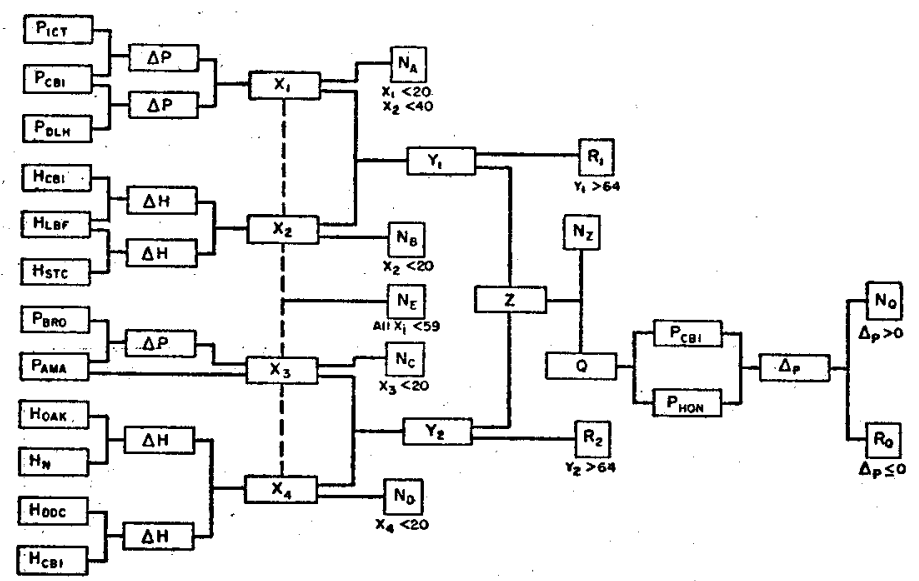

Fiouas 15.-System organization chart. "P" indicates sea level pressure; " $\mathrm{H}$ ", 700-mb. helght. Other symbols indicate values and forecasts explained in the text.

also has its deficiencies as pointed out by the tests of our system. For example, if precipitation occurs in less than one-fourth of all cases, the skill score can be increased if certain sections of the scatter diagram are designated as precipitation-forecast areas even though only one out of four of the cases within those areas is actually a precipitation case. Obviously except for specialized purposes no forecaster wishes to forecast rain with only a 25 percent probability of success.

In determining the $\mathrm{R}$ and $\mathrm{N}$ categories of this system it was desired to have as high a skill score as possible. At the same time, to make the $\mathrm{R}$ catagories acceptable to the forecaster, the percentage of precipitation cases in these categories was kept above 50 . The final percentages for the principal $R$ categories, $R_{1}$ and $R_{2}$, indicate a

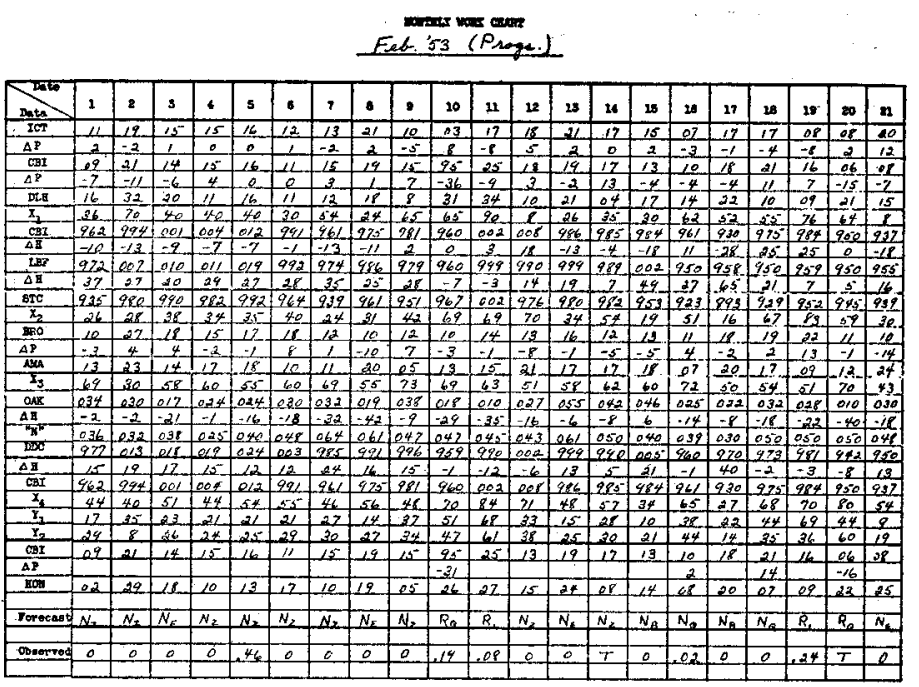

Frgure 16.-Sample Work Sheet. A suggested conventent form to contain an entire month's data. The entries include the basic heights and pressures required, and $d \theta$. rived quantities necessary in determining the system torecasts. Data shown are for first 21 days of Feb. 1953.

decrease in precipitation frequency from 56 percent in the basic data to 42 percent in the test using perfect pronostics (see table 1). Skill scores attained by this system with the developmental data and when applied to independent and actual prognostics are also shown in table 1 .

\section{QUANTTTATIVE FORECASTING}

Included in table 1 is a breakdown, by quantity of precipitation, of the cases of measurable rain falling into each forecast category. Large amounts are infrequent in winter at Des Moines, the normal precipitation for the winter months being, for December: 1.19 in.; January: 1.08 in.; and February: 1.09 in.

The small number of heavy precipitation cases does not afford much opportunity for developing a quantitative forecast procedure. Added to this is the fact that some of the greatest storms threatening Des Moines deposit very little precipitation there when the "arid line," defined earlier, lies to the east of that city.

In spite of these factors, the percentage frequency of the quantitative amounts carries over fairly well from development to test perfect-pronostic data. Little skill in quantitative forecasting is shown by the test on actual prognostic charts.

\section{A COMPARISON WITH THE DISTRICT FORECASTS}

For comparison with the forecasts made by the basic version of this objective system, the original Iowa State forecasts issued by the Chicago District Forecast Center were obtained for eight of the nine test months in the period December 1949 to February 1952-official forecasts for the month of December 1950 were unavailable.

Several definitions were required to change the wording of the district forecasts into categorical forecasts. Since Des Moines lies near the center but in the southwest 
TABLE 1.-Category statistics, contingency tables, skill scores, and percent correct for (1) development data, (2) test using "perfect" prognostics, and (3) test using actual prognostic charts. The skill scores given are calculated by the common definition of skill over chance

Development cases, December 1945, December, January, February 1946-49

\begin{tabular}{|c|c|c|c|c|c|c|c|c|c|c|c|c|c|c|c|c|c|}
\hline \multirow{3}{*}{$\begin{array}{c}\text { Forecast } \\
\text { group }\end{array}$} & \multirow{3}{*}{$\begin{array}{l}\text { Total } \\
\text { cases }\end{array}$} & \multirow{3}{*}{$\begin{array}{l}\text { No rain } \\
\text { or trace }\end{array}$} & \multicolumn{10}{|c|}{ Measurable rain } & \multirow{4}{*}{ 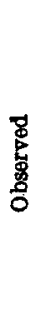 } & \multirow{4}{*}{$\begin{array}{l}\text { Rain.-. } \\
\text { No rain. } \\
\text { Total } \\
\text { Skili s } \\
\text { Percen }\end{array}$} & \multirow{2}{*}{\multicolumn{3}{|c|}{ Forecast }} \\
\hline & & & \multirow{2}{*}{$\begin{array}{l}\text { Number } \\
\text { of cases }\end{array}$} & \multirow{2}{*}{$\begin{array}{l}\text { Percent } \\
\text { of total } \\
\text { cases }\end{array}$} & \multicolumn{2}{|c|}{$0.01-0.09$ inches } & \multicolumn{2}{|c|}{$0.10-0.24$ inches } & \multicolumn{2}{|c|}{$0.25-0.49$ inches } & \multicolumn{2}{|c|}{$\geq 0.50$ inches } & & & & & \\
\hline & & & & & Number & Percent & Number & Percent & Number & Percent & Number & Percent & & & & $\begin{array}{r}17 \\
266\end{array}$ & $\begin{array}{r}57 \\
304\end{array}$ \\
\hline $\begin{array}{l}\mathbf{N}_{\mathbf{A}} \mathbf{B C D} \\
\mathbf{N}_{\mathrm{E}} \\
\mathbf{N}_{\mathbf{z}} \\
\mathbf{N}_{\mathbf{Q}} \\
\mathbf{R}_{1-\mathbf{R}} \\
\mathbf{R}_{\mathbf{Q}}\end{array}$ & $\begin{array}{r}63 \\
73 \\
113 \\
34 \\
45 \\
\mathbf{3 3}\end{array}$ & $\begin{array}{r}63 \\
73 \\
100 \\
30 \\
20 \\
18\end{array}$ & $\begin{array}{r}0 \\
0 \\
13 \\
4 \\
25 \\
15\end{array}$ & $\begin{array}{r}0 \\
0 \\
12 \\
12 \\
56 \\
45\end{array}$ & $\begin{array}{r}11 \\
1 \\
9 \\
12\end{array}$ & $\begin{array}{r}10 \\
3 \\
20 \\
36\end{array}$ & $\begin{array}{l}2 \\
2 \\
8 \\
1\end{array}$ & $\begin{array}{r}2 \\
6 \\
18 \\
3\end{array}$ & $\begin{array}{l}1 \\
2 \\
1\end{array}$ & $\begin{array}{l}\mathbf{3} \\
\mathbf{5} \\
\mathbf{3}\end{array}$ & $\begin{array}{l}6 \\
1\end{array}$ & $\begin{array}{r}13 \\
3\end{array}$ & & & $\begin{array}{l}78 \\
\text { tore: } 0.50 \\
\text { correct }\end{array}$ & 85. & 361 \\
\hline
\end{tabular}

Test cases-perfect prognostics, December 1949, Decomber, January, February 1950-53

\begin{tabular}{|c|c|c|c|c|c|c|c|c|c|c|c|c|c|c|c|c|c|}
\hline \multirow{3}{*}{$\begin{array}{l}\mathbf{N}_{A B C D} \\
\mathbf{N}_{\mathbf{R}} \\
\mathbf{N}_{\mathrm{z}} \\
\mathbf{N}_{\mathbf{Q}} \\
\mathbf{R}_{1-3} \\
\mathbf{R}_{\mathbf{Q}}\end{array}$} & \multirow{3}{*}{$\begin{array}{l}75 \\
63 \\
88 \\
36 \\
52 \\
\mathbf{4 7}\end{array}$} & \multirow{3}{*}{$\begin{array}{l}70 \\
61 \\
83 \\
33 \\
30 \\
\mathbf{3 4}\end{array}$} & \multirow{3}{*}{\begin{tabular}{r|}
5 \\
2 \\
5 \\
3 \\
22 \\
13
\end{tabular}} & \multirow{3}{*}{$\begin{array}{r}7 \\
3 \\
6 \\
8 \\
42 \\
27\end{array}$} & \multirow{3}{*}{$\begin{array}{r}4 \\
2 \\
4 \\
2 \\
6 \\
10\end{array}$} & \multirow{3}{*}{$\begin{array}{r}6 \\
3 \\
5 \\
5 \\
11 \\
21\end{array}$} & \multirow{3}{*}{$\begin{array}{r}1 \\
0 \\
0 \\
10 \\
2\end{array}$} & \multirow{3}{*}{\begin{tabular}{r|}
1 \\
0 \\
0 \\
0 \\
19 \\
4
\end{tabular}} & \multirow{3}{*}{$\begin{array}{l}1 \\
1 \\
4 \\
1\end{array}$} & \multirow{3}{*}{$\begin{array}{l}1 \\
3 \\
8 \\
2\end{array}$} & \multirow[b]{3}{*}{2} & \multirow[b]{3}{*}{4} & \multirow{3}{*}{ 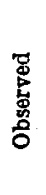 } & & \multicolumn{3}{|c|}{ Forecast } \\
\hline & & & & & & & & & & & & & & $\begin{array}{l}\text { Rain } \\
\text { No rain. }\end{array}$ & $\begin{array}{r}\text { Rain } \\
35 \\
64\end{array}$ & $\begin{array}{r}\text { No rain } \\
15 \\
247\end{array}$ & $\begin{array}{r}\text { Total } \\
50 \\
311\end{array}$ \\
\hline & & & & & & & & & & & & & & $\begin{array}{l}\text { Total } \\
\text { Skill } \\
\text { Perce }\end{array}$ & $\begin{array}{l}99 \\
\text { re: } 0.38 \\
\text { correct }\end{array}$ & t: 78. & 361 \\
\hline
\end{tabular}

Test cases-actual prognostics, December 1949, December, January, February 1950-53

\begin{tabular}{|c|c|c|c|c|c|c|c|c|c|c|c|c|c|c|c|c|c|}
\hline & & & & & & & & & & & & & & & & Forecast & \\
\hline $\begin{array}{l}N_{A B C D} \\
N_{E} \\
N_{z} \\
N_{Q}\end{array}$ & $\begin{array}{r}57 \\
66 \\
125 \\
44\end{array}$ & \begin{tabular}{r|}
47 \\
63 \\
110 \\
37
\end{tabular} & $\begin{array}{r}10 \\
3 \\
15 \\
7\end{array}$ & $\begin{array}{r}18 \\
5 \\
12 \\
16\end{array}$ & $\begin{array}{l}9 \\
3 \\
5 \\
3\end{array}$ & $\begin{array}{r}16 \\
5 \\
4 \\
7\end{array}$ & $\begin{array}{l}5 \\
3\end{array}$ & $\begin{array}{l}4 \\
7\end{array}$ & $\begin{array}{l}4 \\
1\end{array}$ & $\begin{array}{l}3 \\
2\end{array}$ & 1 & 1 & 昰 & $\begin{array}{l}\text { Rain } \\
\text { No rain. }\end{array}$ & $\begin{array}{r}\text { Rain } \\
15 \\
64\end{array}$ & $\begin{array}{r}\text { No rain } \\
35 \\
257\end{array}$ & $\begin{array}{r}\text { Total } \\
50 \\
311\end{array}$ \\
\hline $\begin{array}{l}\mathbf{R}_{1-2} \\
\mathbf{R}_{\mathbf{Q}}\end{array}$ & $\begin{array}{l}36 \\
33\end{array}$ & $\begin{array}{l}27 \\
27\end{array}$ & $\begin{array}{l}9 \\
\mathbf{6}\end{array}$ & $\begin{array}{l}25 \\
18\end{array}$ & $\begin{array}{l}6 \\
2\end{array}$ & $\begin{array}{r}17 \\
6\end{array}$ & $\begin{array}{l}2 \\
2\end{array}$ & $\begin{array}{l}5 \\
6\end{array}$ & $\begin{array}{l}0 \\
2\end{array}$ & $\begin{array}{l}0 \\
6\end{array}$ & 1 & 3 & $\stackrel{\circ}{0}$ & $\begin{array}{l}\text { Total. } \\
\text { Skill } \\
\text { Perce }\end{array}$ & $\begin{array}{l}69 \\
\text { correct: } \\
\text { co.11 }\end{array}$ & $7^{292}$ & 361 \\
\hline
\end{tabular}

TABLE 2.-Comparison of objective and district forecasts for about eight of the test months

\begin{tabular}{|c|c|c|c|c|c|c|c|c|c|}
\hline \multirow{3}{*}{ Forecast used } & \multicolumn{5}{|c|}{ Verifying by precipitation at Des Moines, $0600-1800 \mathrm{csT}$} & \multicolumn{4}{|c|}{$\begin{array}{l}\text { Verifying by precipitation at Des Moines } \\
\text { midnight to midnight, or at stations } \\
\text { within } 35 \text { miles, } 0600-1800 \mathrm{csT}\end{array}$} \\
\hline & & \multicolumn{2}{|c|}{ Forecast } & \multirow{2}{*}{$\begin{array}{l}\text { Skill } \\
\text { seore }\end{array}$} & \multirow{2}{*}{$\begin{array}{l}\text { Percent } \\
\text { correct }\end{array}$} & \multicolumn{2}{|c|}{ Forecsst } & \multirow{2}{*}{$\begin{array}{l}\text { Sklll } \\
\text { score }\end{array}$} & \multirow{2}{*}{$\begin{array}{l}\text { Percent } \\
\text { correct }\end{array}$} \\
\hline & & Rain & No rain & & & Rain & No rain & & \\
\hline $\begin{array}{l}\text { Objective forecast for } 0600-1800 \text { cst day after tomorrow; } \\
\text { latest dats-1230 csr surface chart. }\end{array}$ & $\begin{array}{l}\text { Rain } \\
\text { No rain }\end{array}$ & $\begin{array}{l}10 \\
40\end{array}$ & $\begin{array}{r}24 \\
162\end{array}$ & 0.08 & 73 & $\begin{array}{l}15 \\
35\end{array}$ & $\begin{array}{r}43 \\
143\end{array}$ & 0.06 & 67 \\
\hline $\begin{array}{l}\text { District forecast for } 0600-1800 \text { csT day after tomorrow; } \\
\text { latest data } 1830 \text { csT surface chart. }\end{array}$ & $\begin{array}{l}\text { Rain } \\
\text { No rain }\end{array}$ & $\begin{array}{l}10 \\
42\end{array}$ & $\begin{array}{r}24 \\
160\end{array}$ & 0.07 & 72 & $\begin{array}{l}10 \\
33\end{array}$ & $\begin{array}{r}39 \\
145\end{array}$ & 0.15 & 69 \\
\hline $\begin{array}{l}\text { District forecast for } 0600-1800 \text { cst tomorrow; latest data } \\
1830 \text { csr surface chart. }\end{array}$ & $\begin{array}{l}\text { Rain } \\
\text { No rain }\end{array}$ & 31 & $\begin{array}{r}21 \\
172\end{array}$ & 0.22 & 78 & 24 & $\begin{array}{r}36 \\
157\end{array}$ & 0.31 & 76 \\
\hline $\begin{array}{l}\text { Objective forecast for } 0600-1800 \text { csr tomorrow; latest data } \\
2100 \text { csr } 700-\mathrm{mb} \text {. chart. }\end{array}$ & $\begin{array}{l}\text { Rain } \\
\text { No rain }\end{array}$ & $\begin{array}{l}26 \\
51\end{array}$ & $\begin{array}{r}9 \\
152\end{array}$ & 0.33 & 75 & $\begin{array}{l}37 \\
40\end{array}$ & $\begin{array}{r}23 \\
138\end{array}$ & $\mathbf{0 . 3 6}$ & 74 \\
\hline $\begin{array}{l}\text { District forecast for } 0800-1800 \text { CST today; latest data } 0030 \\
\text { cst surface chart. }\end{array}$ & Rain & $\begin{array}{l}24 \\
35\end{array}$ & 11 & 0.40 & 81 & $\begin{array}{l}35 \\
24\end{array}$ & $\begin{array}{r}25 \\
156\end{array}$ & 0.45 & 80 \\
\hline
\end{tabular}

quarter of the State, statements about the weather for the entire State, or for the central, the south, the west, or the southwest portions, were taken as applying to Des Moines.

Any forecast in which no mention was made of precipitation other than drizzle or flurries was taken as a noprecipitation forecast. All others were interpreted as requiring measurable precipitation for verification. Two classes of precipitation occurrence were recognized: (a) A measurable amount ( $>0.005$ inch) at Des Moines in the 12-hour period 0600 to $1800 \mathrm{csT}$; (b) A measurable amount at Des Moines anytime in the 24-hour period from midnight to midnight, or within the 12-hour period $0600-1800$ CST at any two of four Iowa stations-Ames, Dexter, St.
Charles, and Knoxville - within 35 miles of Des Moines. This latter gives the forecaster credit for near misses in space and time.

Because of the rapid decay of verification scores with time, the difference in time projection between the official forecasts and the forecasts made by the system should be taken into account. In making the forecasts for the day after tomorrow, the district forecaster has before him the surface map for $1830 \mathrm{csT}$. In contrast, the last chart available in making the prognostic chart used by the objective system is that for $1230 \mathrm{csT}$. The district forecasts for tomorrow, in table 2 , bracket the objective forecast with which they are.compared, in the one case by being made without use of the $2100 \mathrm{csr} 700-\mathrm{mb}$. chart and 
in the other case by having the advantage of information on the 0030 CST surface chart.

It can be seen in table 2 that the variation in the scores is definitely a function of the projection time of the forecast. There is little to indicate a significant difference between the objective method and the district forecast except perhaps when credit is given for near misses. However, this alternative definition of the occurrence of precipitation was made on the recommendation of a district forecaster as a means of giving credit for what the forecaster feels is a satisfactory job done when the projection time is as long as $36-48$ hours. It is quite likely that his forecast is designed with such a definition in mind while the objective system is specifically designed to forecast only for the 12-hour period at Des Moines.

Thus we reach the same conclusion as that of most other objective forecast studies. It is possible to devise an objective forecast system, based on a small number of fairly crude parameters, that will attain very nearly the same degree of success as that of an experienced and able forecaster, but it is difficult, even with a very complex system, to exceed his record in the mean. This is particularly true if the forecaster is aware of the principles upon which the system is based.

\section{APPLICATION OF THE FORECASTS TO OTHER STATIONS}

There often arises the important question of how large an area is really being forecast for successfully by a system which, like this one, depends on parametric data from stations far from the point of the forecast. One might also ask whether the point for which the system was designed lies in the center of the area and, if not, whether there is not some other point nearer the center for which the system forecasts with greater skill. It was relatively simple to verify the forecasts of precipitation for Des Moines against the precipitation observed at surrounding stations. A first group of stations was selected and from the results, a second group was added to the list as follows:

$\quad$ First group
Chicago, Ill.
Moline, Ill.
Minneapolis, Minn.
Sioux City, Iowa
Kansas City, Mo.
St. Louis, Mo.

First group

Chicago, III

Moline, Ill.

Sioux City, Iowa

St. Louis, Mo.

\author{
Second group \\ Indianapolis, Ind. \\ Madison, Wis. \\ Omaha, Nebr. \\ Grand Island, Nebr. \\ Wichita, Kans. \\ Oklahoma City, Okla. \\ Little Rock, Ark. \\ Springfield, Mo. \\ Columbia, Mo.
}

The application of the Des Moines forecasts to other stations indicates a rapid falling off of skill to the north (fig. 17). The skill scores tend to be higher at Moline than at Des Moines, and remain at a high level to the south even as far away as Little Rock.

If the results shown in figure 17 are reliable, we are led to conclude that objective forecast systems may very well cover geographically uniform areas as large as 100,000 square miles. Thus a limited number (perhaps

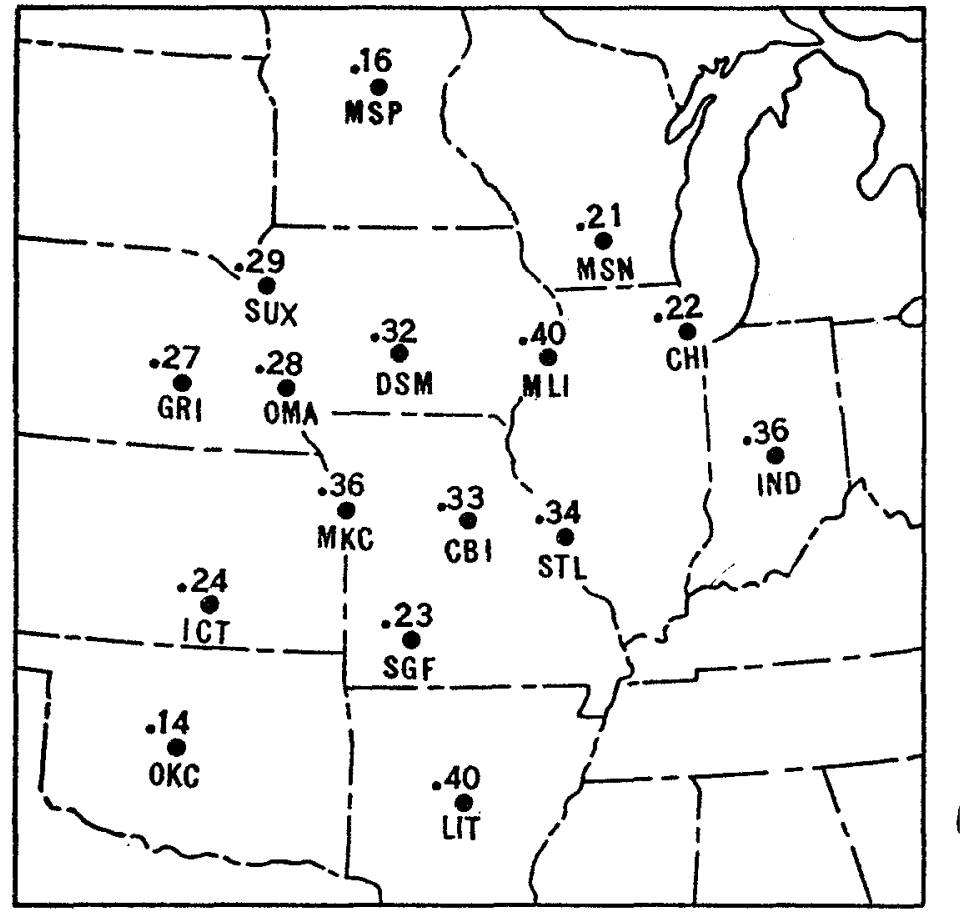

FIOURE 17.-Skill scores attained at various points in the Midwest when forecasts for Des Moines, made by applying the system to data from perfect prognostic charts for the 12 test months in the period, December 1949 to February 1952, are verifled against the precipitation occurring at the tadicated stations.

30 or 40) of carefully designed systems could be used to forecast precipitation during a particular period for the entire country.

\section{CONCLUSION}

The simplicity of the system and of the parameters involved might make the reader wonder whether better results could not be obtained through some elaboration. Much time was spent in attempting to improve the results by using a variety of parameters from synoptic charts available to the forecaster or taken from the prognostic chart. Although many types of parameters used in other objective methods were tested, their use did not increase the skill already attained. Another question might arise with respect to the omission of parameters from upper levels other than $700 \mathrm{mb}$. It was thought inadvisable to use parameters from prognostic charts which, like those for the 500-, 400-, 300-, and 200-mb. levels, have been constructed for only short, irregular periods, because the skill of such parameters could not be adequately tested.

The primary aim of this work was to find a means by which the features of the prognostic charts currently issued could be used to forecast precipitation. That the flow pattern can have such an ability has been demonstrated, at least with the perfect prognostic. However, the fact that the skill score of the system diminishes so greatly when it is tested upon actual prognostics, indicates that the average skill of prognosticators is not great enough 
at present to allow optimum use of asystem such as this. There are several ways in which prognostic charts may be improved. Among these are more careful selection and training of prognosticators, and improvement of the methods they utilize.

As matters now stand, the skill of the system when tested upon parameters taken from actual prognostics is sufficiently mediocre to suggest that it might be more expedient to bypass the prognostic chart by using parameters taken from the maps available to the forecaster at the time he is making his forecast. This is the type of objective technique used by Schmidt $[7,8]$ in several recent papers. After such a system had been developed to its fullest extent, an attempt could be made to improve the results by applying parameters taken from prognostic charts available to the forecaster. In this way, at least the main portion of the system would not be affected by the uncertainties of the prognostic procedure.

At present it seems likely that the most promising means of improving the prognostic chart is through the use of numerical methods now being developed to solve physical equations with the aid of the electronic computer. Since the product of numerical methods may be in the form of the future distribution of quantities such as vertical motion directly associated with the precipitation process, it is not unlikely that the precipitation forecast of the future will be completely objective-produced by the computer directly from the raw data.

\section{REFERENCES}

1. J. G. Charney, "Dynamic Forecasting by Numerical Process," Compendium of Meteorology, American Meteorological Society, Boston 1951, pp. 470-482.

2. W. H. Klein, "An Objective Method of Forecasting Five-Day Precipitation for the Tennessee Valley," U. S. Weather Bureau, Research Paper No. 29, April 1949, 60 pp.

3. L. P. Carstensen, and A. V. Hardy, Relation of Precipitation to the Pressure Pattern in New York City Area in Winter, U. S. Weather Bureau, 1951. (Unpublished.)

4. C. L. Bristor, Relating Prognostic Charts to Winter Precipitation at Sioux City, Iowa, U. S. Weather Bureau, 1952. (Unpublished.)

5. C. L. Bristor, Selecting Research Problems for Forecast Improvement, U. S. Weather Bureau, 1952. (Unpublished.)

6. H. Riehl et al. "Forecasting in Middle Latitudes," Meteorological Monographs, vol. I, No. 5, American Meteorological Society, June 1952.

7. R. C. Schmidt, "A Method of Forecasting Occurrence of Winter Precipitation Two Days in Advance," Monthly Weather Review, vol. 79, No. 5, May 1951, pp. 81-95.

8. R. C. Schmidt, "A Method of Forecasting Precipitation 28-40 Hours in Advance During October," Monthly Weather Review, vol. 79, No. 6, June 1951, pp. 116-124. 